\title{
Production by intertidal benthic animals and limits to their predation by shorebirds: a heuristic model
}

\author{
Theunis Piersma \\ Rijksdienst voor de IJsselmeerpolders, PO Box 600, 8200 AP Lelystad, The Netherlands \\ and \\ Zoological Laboratory, University of Groningen, PO Box 14, 9700 AA Haren, The Netherlands
}

\begin{abstract}
This review examines the question whether the cumulative amount of benthic biomass removed by feeding shorebirds on a certain intertidal area is limited by the renewal rate of benthic food stocks. Limitations of current methods to estimate both predatory impact by shorebirds and harvestable benthic secondary productivity are discussed first. A heuristic model is then presented which summarises all the known interrelated causal processes (mechanisms) that connect food stocks and shorebird predation. Since the majority of terms in the model are operational, it is possible to translate them into a simulation-model for a specific predator-prey situation. Any influence of benthic food stocks on densities of feeding shorebirds works via the predator's selection of acceptable prey (i. e. availability and profitability). Short-term densities of feeding shorebirds are thus limited directly by the density of acceptable prey. Cumulative shorebird predation may be limited by the production of acceptable biomass, which is argued to be the crucial measurement to make to investigate whether benthic food supply limits shorebird predation in the long term. The heuristic model presented here can be modified to apply to other trophic systems.
\end{abstract}

\section{INTRODUCTION}

A key problem in understanding the non-breeding distribution of shorebirds is whether or not their use of particular intertidal sites is limited by the benthic food supply (Evans \& Dugan 1984, Goss-Custard 1985). In saying this, it is of immediate importance to state what is meant by 'their use', by 'being limited' and by 'benthic food supply'. As I shall try to disentangle causal processes which relate the production of benthic food resources to the amount of that production eventually harvested by foraging shorebirds, 'their use' will be defined here as the cumulative amount of benthic biomass removed by shorebirds at a particular site over a season or a year. (The term 'predation pressure' is reserved for the description of interactions between one predator and one prey species.) The question of what determines (instantaneous) shorebird densities ('their use' in the short term) will be implicit in the following discussions. Benthic food supply consist of 'what there is' (standing stock/crop or biomass pre- sent), 'what is lost' (predation and emigration) and 'what extra comes to it' (production/somatic growth and immigration). It is, of course, the third term which defines sustainable benthic yield. If, on a seasonal or an annual basis at a particular site, shorebirds eat the same amount or more than can be replaced by production and immigration, the benthic food supply would appear limiting. An important question may therefore be: do shorebirds (sometimes) harvest most or all of the benthic food that becomes available to them through production (plus immigration)?

Large losses due to predation by shorebirds relative to average macrobenthic standing crops (i.e. depletion: Zwarts \& Drent 1981, Piersma \& Engelmoer 1982, reviews in Goss-Custard 1980, 1984) or relative to annual production (Smit 1981) are usually considered to indicate limiting food supplies (see Newton 1980 for some early warnings). The absence of measurable depletion then, is interpreted as food not being in short supply (Duffy et al. 1981, Schneider 1985a).

Believing that benthic productivity can predict the 
bird density in an estuary, Wolff (1983) went so far as to formulate the hypothesis that the number of bird-days spent on a certain intertidal area is dependent on estuarine primary production because of the coupling by estuarine benthos'. In other words, benthic secondary productivity bears a direct relation to predatory impact by waders and other estuarine birds, and therefore sets the limits. This view implies that measurements of secondary productivity, by marine biologists, can be compared with estimates of the amount of benthic biomass removed by shorebirds (cf. Schneider 1981) to see whether benthic food supply is the limiting factor.

In this paper I set out to examine the methodologies of measurement of shorebirds' predatory impact and of benthic secondary productivity. My aim is to explore the question whether the 2 fields of study can be profitably linked in order to find out whether the cumulative amount of benthic biomass removed by shorebirds at a certain site is limited by benthic food supply. In bringing all causal relations between benthic animals and feeding shorebirds together in a dynamic model, I have tried to take the issues a step further than Baird et al. (1985) in their recent review of this field of research.

\section{MEASURING SHOREBIRD PREDATION}

Three types of investigation have been used to measure the cumulative amount of benthic biomass removed by shorebirds from a certain intertidal area: (1) direct measurement of intake rates by shorebirds, (2) estimates of the total energy requirement of the shorebird community on a certain area, and (3) application of predator exclosure devices.

Total predation pressure estimates based on direct visual measurements of intake multiplied by the densities of the predators have hitherto only been published for studies of large-bodied shorebird predators feeding on well-defined large-sized prey: oystercatchers Haematopus spp. (Horwood \& Goss-Custard 1977. O'Connor \& Brown 1977, Zwarts \& Drent 1981, Sutherland 1982b, Hockey \& Branch 1984, Zwarts \& Wanink 1984), curlews Numenius arquata (Zwarts \& Wanink 1984) and gulls Larus spp. (Ambrose 1986).

The most widely used method to estimate the amount of benthic biomass removed by shorebirds has been to translate counts of shorebirds on certain areas (densities) into estimates of total metabolic demands of entire shorebird communities at the sites, via a series of predictive equations and assumptions (Hulscher 1975, Swennen 1976, Wolff et al. 1976, Goss-Custard 1977, Summers 1977, Evans et al. 1979, Hale 1980, Puttick 1980, Grant 1981, Smit 1981, Bildstein et al. 1982,
Piersma \& Engelmoer 1982, Hockey et al. 1983). The assumptions involve: predictive equations of energy requirements from body mass; the relative requirement of free-living individuals at different times of the year and at different physiological states; average energetic values of the food types; and digestive efficiencies This kind of estimate of predatory impact is clearly very susceptible to inaccuracies in the assumptions, and requires extensive data on metabolic requirements. These have, until recently, been unavailable for shorebirds (but see Speakman 1984, Kersten \& Piersma 1987).

The third approach, which has met most popularity in the New World, is to use cages to exclude shorebirds, but not other benthic predators such as crabs, shrimps and fishes, from foraging on certain areas. The differences between standing crop outside and inside the predator exclosure after periods of predation are taken to be indicative for the predatory impact of shorebirds (Hancock \& Urquhart 1965, Goss-Custard 1977, Boates \& Smith 1979, Bloom 1980, Duffy et al. 1981, Schneider \& Harrington 1981, Walters et al. 1981, Quammen 1984, Schneider 1985b). In some studies, cages to exclude both avian and non-avian benthic predators were applied (Kent \& Day 1983, Quammen 1984). A comparable approach, of using exclusion cages, has been extensively used by marine biologists to study the complexities of benthic 'community structure' (Young et al, 1976, Edwards \& Huebner 1977, Virnstein 1977. 1979, Arntz 1978, Reise 1978, 1985, Peterson 1979, Holland et al. 1980, Nelson 1981, Mahoney \& Livingston 1982, Federle et al. 1983, Ambrose 1984, Botton 1984a, b, Summerson \& Peterson 1984, Gee et al. 1985). The interpretation of the results of exclosure experiments is sometimes difficult because the experimental cages may have other effects than simply excluding shorebird predation (Hulberg \& Oliver 1980, Quammen 1981). Sediment alteration, the inclusion or attraction of unwanted predators ('other predators move in to reap the reward': Goss-Custard 1980), and selective immi- or emigration of the studied prey species, are the most common problems. Exclosures are therefore most likely to be successfully applied in short-term studies in areas with little environmental dynamics (sediment alteration), and during periods of heavy shorebird predation (measurable effects, and a relatively smaller impact of possible alternative predators). So far, only Piersma (1986b) has attempted to compare the outcomes of all 3 methods of measuring shorebirds' predatory impact. In that study, the different methods to estimate the cumulative predation by migrating shorebirds on a population of the polychaete worm Nereis diversicolor in a small estuary in Morocco during 2 mo in spring, gave results ranging from 85 to $120 \%$ of the average of the 3 estimates. 


\section{PRODUCTION OF BENTHOS}

The labour-intensive field and laboratory work, and complicated calculations, that are required to arrive at estimates of secondary production in benthic organisms are usefully summarized by Crisp (1984). I refer the reader to his paper for details. A shorthand for summarizing the productivity of a given species on an annual basis is the $\mathrm{P} / \mathrm{B}$-ratio (annual production divided by average biomass). Comparisons of P/B-values among benthic species have led to the generalization that $\mathrm{P} / \mathrm{B}$-values are negatively correlated with lifespan (that is: the shorter the lifespan (i. e. average age!), the higher the relative productivity) with no great differences in the lifespan/relative productivity relationship between different taxonomic groups (Blueweiss et al. 1978, Robertson 1979). This means that regular measurements of benthic biomass, with some knowledge about the age distribution and the life histories of the benthic species under study, could lead to useful estimates of the annual benthic production at a certain site (Beukema 1981). This is a hopeful perspective for the shorebird-biologist interested in the secondary productivity of a study site (see e.g. Piersma 1982).

There remain, however, at least 3 problems inherent to the desired comparisons between the relevant values for benthic production and the part of it removed by feeding shorebirds. The first is due to the fact that not all the produced benthic biomass is always available and acceptable to shorebirds (Goss-Custard 1969, Goss-Custard \& Charman 1976, Evans 1979, Pienkowski 1981, Piersma 1986a, Zwarts \& Wanink unpubl.). For example, availability of benthic animals may be lowered by the animals burying deeper into the sediment (Reading \& McGrorty 1978) or by showing less visible surface activity (Pienkowski 1983b). And even if a prey is available to a specific predator it need not always be acceptable: it may lack a critical nutrient or it may be smaller than the lowest acceptable size (Tinbergen 1981, Zwarts \& Wanink 1984). The overall availability of benthos may well differ significantly between different geographical areas. For example, during winter the biomass of acceptable benthic organisms is very low on the Banc d'Arguin in Mauritania (Engelmoer et al. 1984), but more than three-quarters of it is found in the top $5 \mathrm{~cm}$ of the sediment and therefore easy to come by for small-bodied shorebirds. This contrasts with the situation in western Europe, where in winter much of the higher total acceptable biomass is found deeper than $5 \mathrm{~cm}$ in the substrate (Reading \& McGrorty 1978, Zwarts 1984, pers. comm.)

The second problem is related to current methods of measuring and calculating secondary benthic production (this point is illustrated in Fig. 1). The usual calcu-

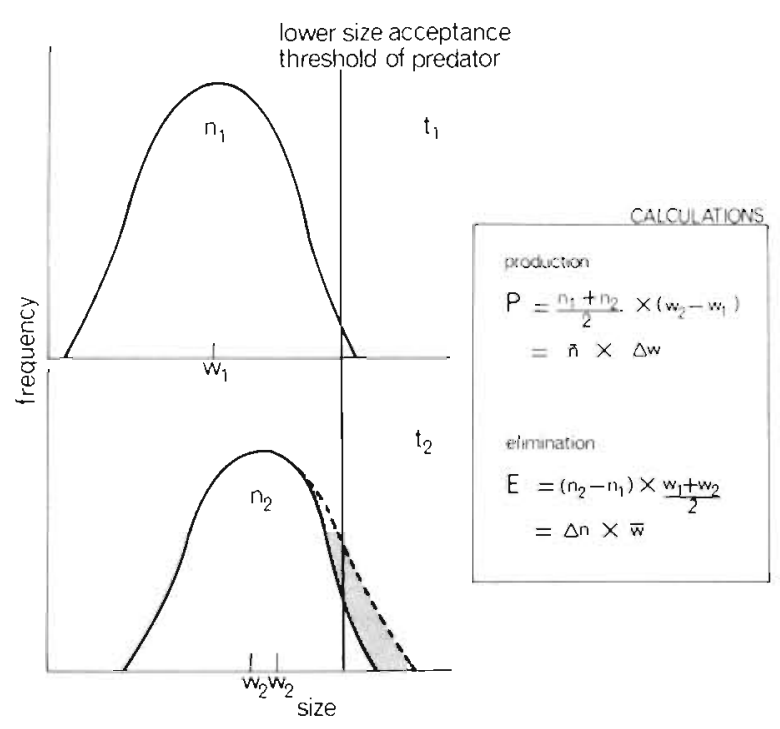

Fig. 1. Explanation of the methods to calculate production and elimination in one growing cohort of a benthic species (after Crisp 1984). If in the lower size-frequency graph the hatched area is included, the 'total' curve shows how the cohort grows in the absence of size-selective predation. If the hatched area is not included, the remaining curve shows the 'growth' of the cohort with the selective predation on the individuals larger than the lower size acceptance threshold

lation methods for production $(\mathrm{P})$ and elimination $(\mathrm{E})$ of a cohort of a given benthic species assume that mortality within a cohort is independent of the individuals' size. However, in several shorebird species lower acceptance thresholds for prey acceptability have been shown (above, Zwarts \& Wanink 1984). Indeed, selection for larger sized prey than the available average is probably a common phenomenon in shorebirds (e.g. Ens 1982, Hulscher 1982, Sutherland 1982a, Howard \& Lowe 1984) and other benthic predators (e.g. crabs: Kneib 1982, Botton 1984b). If mortality of a benthic species is mainly due to a predator with such a lower acceptance threshold (i.e. only the large individuals of a cohort are fed upon), then the growth increments (W2-W1), and therefore production (P), are underestimated. In such cases, part of the productivity escapes the calculations unnoticed, straight into the stomachs of the predators. In theory this can lead to mortalities based on actual intake rates of the predator being higher than concurrent production/elimination estimates based on cohort-growth analyses.

Thirdly, shorebirds may feed on regenerating parts of benthic organisms (e.g. curlews feeding on the siphons of Scrobicularia plana, Ens \& Zwarts 1980), the production of which again escapes the calculations. Although this type of predation is known to be mainly due to shrimps, crabs and flatfishes (De Vlas 1979, 1985, Peterson \& Quammen 1982, Zwarts 1986), tail- 
and siphon-feeding by shorebirds may well prove to be a significant predation pressure in some situations.

\section{A HEURISTIC MODEL}

Since there are various practical problems and causal processes that interfere crucially with attempts to interpret any relationships between secondary productivity and its exploitation by shorebirds, I began to doubt the value of the generalizations by e.g. Schneider (1981) and Wolff (1983). More importantly, I wondered whether a comparison between estimates of shorebirds' predatory impact and benthic production can ever show us whether or not cumulative shorebird predation is limited by food supply. This was the incentive to summarize, in the form of a heuristic model, all the known causal processes that relate benthic stocks to shorebird predation and shorebird predation to benthic stocks.

In the model, shown in Fig. 2, I have tried to incorporate all the known direct cause-effect relations in benthos-shorebird interactive systems. Published correlations (e.g. Myers et al. 1980, Pienkowski 1983a, c) were examined to see whether the relation was direct or worked via one or more other processes, Yet, aiming at being comprehensive made this model more complicated than might be necessary for any given situation where only part of the causal processes (mechanisms) play a role. Therefore, for most specific situations the model can be simplified to contain only the mechanisms which are (considered) crucial. Although the model in Fig. 2 describes in principle only the interactions between one benthic invertebrate and one shorebird species, it can be extended to include other shorebird species by 'adding' one or more such models

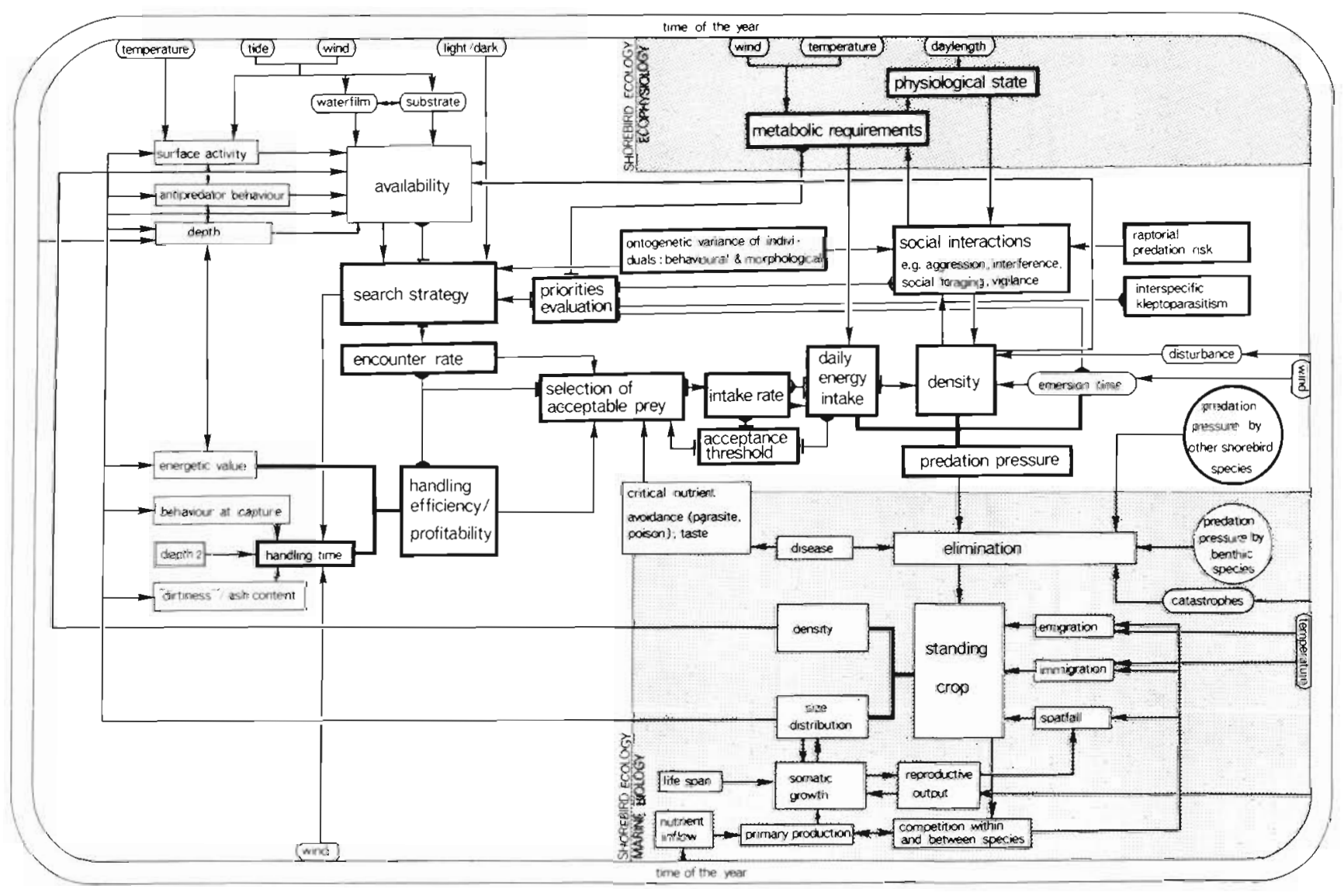

Fig. 2. A heuristic model to describe the direct causal interactions between a shorebird species and one of its benthic prey at a particular intertidal site. Heavy rectangles: attributes of shorebird predators; light rectangles: attributes of macrobenthic prey; rounded rectangles: non-biological variables; circles: links to other dimensions (shorebird/macrobenthic species interaction systems). Key:

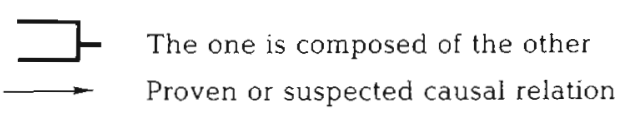

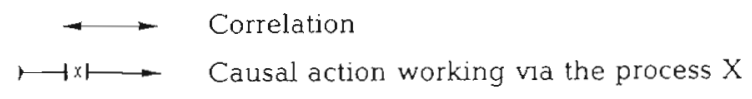


(at the top circle on the right). A limitation is that predation by (benthic) predators other than shorebirds is entered as a constant. Since there may well exist feedback relationships between shorebird and benthic fish- and invertebrate-predation, the model should eventually be extended to include the other predator categories. Currently, the detailed knowledge required for building such an extension is not yet available.

Table 1. Definitions of biological terms in the model of Fig. 2 in alphabetical order. OT: operational term; (N)OT: not-yet operationalized term; NOT non-operational term. Examples of units are given in brackets

\begin{tabular}{|c|c|c|c|c|}
\hline Term & Definition & $\mathrm{OT}$ & (N)OT & NOT \\
\hline Acceptance threshold & $\begin{array}{l}\text { Minimally required profitability of ingested prey }\left(\mathrm{mg} \mathrm{s}^{-1}\right) \text {; may additionally } \\
\text { incorporate minimal critical nutrient content (protein, mineral) }\end{array}$ & $x$ & & \\
\hline Antipredator behaviour & Tactics to remain out of predator's reach (burying, swimming or running away) & & $\times$ & \\
\hline Availability & Being detectable and within reach of a shorebird's bill & & $\times$ & \\
\hline Behaviour at capture & Intensity of body movement after capture & & & $\times$ \\
\hline $\begin{array}{l}\text { Competition within } \\
\text { and between species }\end{array}$ & $\begin{array}{l}\text { Effects on somatic growth or reproductive output with increased densities } \\
\text { of other macrobenthic animals }\end{array}$ & & & $x$ \\
\hline Daily energy intake & (Required) energy intake per day $\left(\mathrm{kJ} \mathrm{d}^{-1}\right)$ & $\times$ & & \\
\hline Density (macrobenthos) & Number of benthic individuals per unit area & $\times$ & & \\
\hline Density (shorebirds) & Number of shorebirds per unit area & $\times$ & & \\
\hline Depth & Distance between upper part of prey and surface of the sediment & $x$ & & \\
\hline 'Dirtiness'/ash content & Proportion ash $\left(g\right.$ ash $\left.[g \text { AFDW }]^{-1}\right)$ & $\times$ & & \\
\hline Disease & Impaired health due to poisoning or parasites & $\times$ & & \\
\hline Emigration [rate] & $\begin{array}{l}\text { Movement away from study area (number per unit area per unit time }\left[\mathrm{n} \mathrm{m}^{-2} \mathrm{~d}^{-1}\right. \\
\left.\text { or g AFDW } \mathrm{m}^{-2} \mathrm{~d}^{-1}\right] \text { ) }\end{array}$ & $x$ & & \\
\hline Encounter rate & Number of contacts between predator and prey per unit time & $x$ & & \\
\hline Energetic value & $\mathrm{kJ}$ per unit mass $\times$ ingested mass $(\mathrm{kJ})$ & $\times$ & & \\
\hline Primary production & Amount of food for benthos per unit area per unit time & $\times$ & & \\
\hline Handling time & $\begin{array}{l}\text { Time between locating a prey and swallowing it (alternatively: time needed } \\
\text { for prey ingestion and therefore lost for searching) (s) }\end{array}$ & $x$ & & \\
\hline Immigration [rate] & Movement into the study area, per unit time & $\times$ & & \\
\hline Intake rate & Ingested energy per unit foraging time $\left(\mathrm{mg} \mathrm{AFDW} \mathrm{s}^{-1}\right)$ & $\times$ & & \\
\hline $\begin{array}{l}\text { Interspecific } \\
\text { kleptoparasitism }\end{array}$ & Risk of losing a prey to another species & & $x$ & \\
\hline Life span & Duration of life (yr) & $x$ & & \\
\hline Metabolic requirement & Minimum requirement of critical nutrient or energy, per unit time & $x$ & & \\
\hline Elimination & Loss of benthic biomass per unit area per unit time (g AFDW m $\left.\mathrm{m}^{-2} \mathrm{~d}^{-1}\right)$ & $\times$ & & \\
\hline Nutrient inflow & Amount of nutrients available for primary production per unit time and area & $x$ & & \\
\hline Ontogenetic variance & $\begin{array}{l}\text { Variability between individuals in morphology and abilities due to variations in } \\
\text { experience (age, place and way of upbringing) and genotype }\end{array}$ & & & $x$ \\
\hline Physiological state & $\begin{array}{l}\text { Whether the bird is in the process of e.g. premigratory fattening, territory } \\
\text { settlement, egg laying, moult }\end{array}$ & & $x$ & \\
\hline Predation pressure & Amount of prey killed per unit area per unit time & $x$ & & \\
\hline Priorities evaluation & $\begin{array}{l}\text { Decision process to evaluate required intake level against available time, } \\
\text { raptorial predation risk, other risk, etc. }\end{array}$ & & $x$ & \\
\hline Raptorial predation risk & Risk of becoming the prey of a raptor (mortality rate $\mathrm{d}^{-1}$ ) & $x$ & & \\
\hline Reproductive output & Amount of eggs and sperm produced per unit area or per individual & & $\times$ & \\
\hline Search strategy & Way to detect and capture available prey & & & $\times$ \\
\hline $\begin{array}{l}\text { Selection of } \\
\text { acceptable prey }\end{array}$ & $\begin{array}{l}\text { Discrimination criteria for whether or not to capture, handle and ingest } \\
\text { a detected prey }\end{array}$ & & $\times$ & \\
\hline Size distribution & Frequency distribution of size classes & $\times$ & & \\
\hline Social interactions & Way that individuals on a certain area interact & & & $\times$ \\
\hline Somatic growth & Flesh production per individual per day (mg AFDW ind ${ }^{-1} \mathrm{~d}^{-1}$ ) & $x$ & & \\
\hline Spatfall & $\begin{array}{l}\text { Settlement of youngest bottom-stages (not necessarily after a planktonic phase) } \\
\text { on study area (numbers } \mathrm{m}^{-2} \mathrm{~d}^{-1} \text { ) }\end{array}$ & $x$ & & \\
\hline Standing crop & Total biomass per unit area (g AFDW m-2) at any moment & $x$ & & \\
\hline
\end{tabular}


To make perfectly clear what I mean, the definitions of the biological terms in the model are presented in Table 1. Apart from giving these definitions, I also indicate whether the terms are operational (quantifiable) or non-operational (of heuristic value only). Operational values are required to translate the model into simulation models for specific situations and purposes (Peters 1977).

A first point that emerges from studying the model (Fig. 2) is that the interactions between benthic standing crop and density of shorebirds work via several series of related causal processes, or 'feedback loops'. An important feedback loop in Fig. 2 is the one which shows the relations between social (behavioural) interactions of feeding shorebirds and their (instantaneous) density. Since intake rate is (eventually) negatively affected by increases in bird density (via one direct mechanism - interference - and indirectly via series of causal processes: Fig. 2), bird densities may reach the level where additional birds have to leave the site to feed elsewhere because their intake remains below the required rate. Especially in dispersed-feeding shorebirds, which are rather prone to feeding interference (Goss-Custard 1980, 1984, 1985), this may already happen amidst a relative plenty of food. Indeed, such a behaviourally determined limitation of instantaneous feeding densities may, cumulatively over a season, prohibit the depletion of benthic food stocks. Flock-feeding shorebird species are less sensitive to feeding interference (Goss-Custard 1985) and are therefore more likely to deplete a food supply. Flock-feeding shorebirds, then, are most likely to be limited by benthic secondary productivity. Given the above possibilities, it is clear that the block 'social interactions' in Fig. 2 is an important component of the model. However, the block is also rather complicated and, being mainly concerned with the benthosshorebird interactions, I have not ventured to try and dissect it into its own building blocks and the detailed cause-effect relations. A comprehensive review has, however, been written by Myers (1984).

The notion that profitability sets a threshold for the acceptability of a prey is borrowed from and supported by recent studies of optimal foraging (theory) (Krebs et al. 1983). The importance of the intermediate causal steps between benthic stocks and shorebird densities is further exemplified in a simplified version of this feedback loop (Fig. 3). Any influence of benthic standing crop on feeding shorebird densities 'works' via the selection of acceptable prey (i.e. availability and profitability), and therefore any limits to shorebird predation will be set by these key processes.

In the short term, (instantaneous) shorebird predation (i.e. feeding shorebird densities) will be directly limited by the density of acceptable prey. It follows that in the long term, cumulative shorebird predation will also be limited by the production (including immigration) of acceptable prey. In Fig. 3 the feedback loop between benthos and shorebirds is called an organismic explanatory pathway to contrast with the trophic explanatory pathway (as used in other trophic ecosystem/foodweb models: Milne \& Dunnet 1972, Wiens \& Dyer 1977, Furness 1978, Warwick et al. 1979). The latter, non-mechanistic, way of reasoning implies direct relations between primary and secondary production and density of (shore-jbirds. Boldly stated, it tries to discover the limits set by food supply to shorebird densities by 'simply' plotting shorebird density as a dependent variable of benthic standing crop or benthic production. However, by not taking the causal pro-

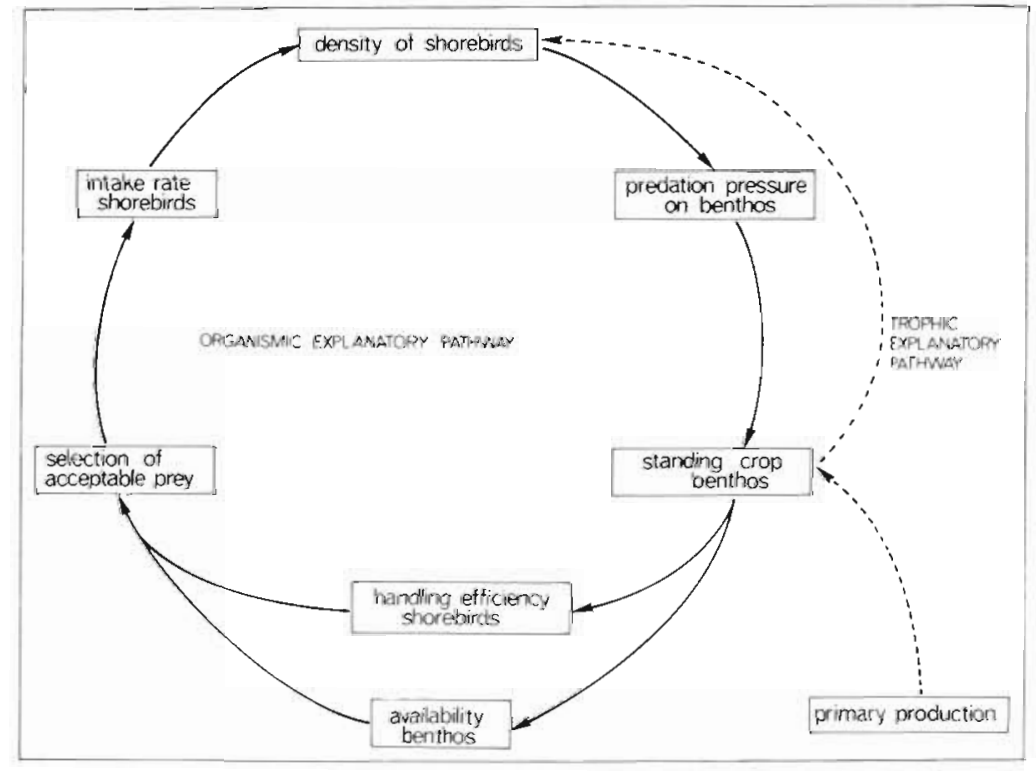

Fig. 3. Simpiified scheme of the main feedback loop between benthos and shorebirds in Fig. 2 (the causal explanatory pathway). On the right an alternative explanatory pathway (the 'trophic') is outlined 
cesses into account, it is logically impossible to find the limits set by benthic productivity to shorebird predation.

A third important feedback loop (which is in Fig. 2 analysed in rather less detail than the former), is the pattern of interactions within benthic prey populations. Such interactions may have important implications for studies of predation, as is shown by the findings of Kent \& Day (1983). They showed, in a nereid polychaete, that when losses of adults were large as a consequence of predation, the recruitment of (fast-growing) juveniles was high. For this reason measured densities of a benthic prey species remained constant over the study period, despite intensive simultaneous predation. In general, this is most likely to happen in benthic invertebrates with short generation times and long reproductive seasons. It again means, however, that the absence of measurable depletion cannot be interpreted straightforwardly (e.g. Duffy et al. 1981, Schneider 1985a). In fact, this observation does not tell us anything about the question whether or not food is in short supply.

\section{DISCUSSION}

It is now time to consider which are the crucial measurements to make on benthic productivity and shorebird foraging in order to find out whether food supply limits cumulative shorebird predation. I think that the crucial measurement here is the production of acceptable biomass. This is the renewal rate of organisms acceptable as food for a certain species of shorebird. If this renewal rate were to be measured and compared to actual predation pressure it could in principle be shown whether food supply sets the limits in the long term. (It does so if predation pressure equals renewal rate.) Note that in the short term, at prey densities too low to satisfy the predator, renewal rates may well exceed removal rates. Although instantaneous shorebird feeding densities are food-limited, cumulative shorebird predation is not limited by the production rate of acceptable biomass in such a case. Acceptable biomass production can thus only be limiting if a site provides minimum (threshold) densities of the favoured prey (see Hulscher 1982, p. 138, for an example.)

That the proposed approach is possible indeed, is suggested by recent work of Zwarts \& Wanink (1984), on the predation of oystercatchers and curlews on clams Mya arenaria. Having shown the existence and numerical value of lower size acceptance and availability (depth) thresholds for both predator species, these authors went on to calculate the evolution of densities of acceptable size classes of clams in the course of 5 seasons. Comparing the declines in densities of vulner- ably sized clams in 2 periods of predation to measured predation pressure, Zwarts \& Wanink estimated that in 2 seasons the oystercatchers took respectively $63 \%$ and almost $80 \%$ of the clams acceptable to them. In the absence of alternative prey, the latter estimate would indicate that food supply almost limited oystercatcher predation at their study site. Although Zwarts \& Wanink's study does not present 'production' in marine biological terms, it does show the kind of field observations needed to fruitfully link benthic production and shorebird predation studies.

The great majority of models on energy flow in ecosystems, which are often designed to examine possible food limitations, do not take into account the availability of prey and the predator's selectivity (e.g. Wiens \& Dyer 1977, Furness 1982). This may reflect the sparsity, and the difficulty of collecting, the relevant observations. However, the approach advocated here, to disentangle the causal processes operating in estuarine food-webs, obviously also applies to other ecosystems. Better predictions on food limits to the abundance of top-predators therefore require more efforts on analysing trophic mechanisms, i.e. detailed feeding ecological work.

Acknowledgements. The theme of this paper was developed during co-operative fieldwork and many discussions with all the 'wader people' from Groningen, Texel and elsewhere. Among them, I am especially grateful to Leo Zwarts and John D. Goss-Custard for all the time we could spend talking. Their comments and those of Jerry A. Hogan, Wim J. Wolff, Rick Looyen, Rudi H. Drent and J. J. Beukema helped a lot to improve the manuscript.

\section{LITERATURE CITED}

Ambrose, W. G., Jr. (1984). Role of predatory infauna in structuring marine soft-bottom communities. Mar. Ecol. Prog. Ser. 17: 109-115

Ambrose, W. G., Jr. (1986). Estimate of removal rate of Nereis virens (Polychaeta: Nereidae) from an intertidal mudflat by gulls (Larus spp.). Mar. Biol. 90: 243-247

Arntz, W. E. (1978). Results and problems of an 'unsuccessful' benthos cage predation experiment (western Baltic). In: Keegan, D. F., O'Ceidigh, P., Boaden, P. J. S. (ed.) Biology of benthic organisms. Pergamon Press, New York, p. 31-44

Baird, D., Evans, P. R., Milne, H., Pienkowski, M. W. (1985). Utilization by shorebirds of benthic invertebrate production in intertidal areas. Oceanogr. mar. Biol. A. Rev. 23: 573-597

Beukema, J. J. (1981). The role of larger invertebrates in the Wadden Sea ecosystem. In: Dankers, N., Kühl, H., Wolff, W. J. (ed.) Invertebrates of the Wadden Sea. Balkema, Rotterdam, p. 211-221

Bildstein, K. L., Christy, R. L., de Coursey, P. (1982). Energy flow through a South Carolina salt-marsh community. Wader Study Group Bull. 34: 35-37

Bloom, S. A. (1980). An intertidal soft-sediment avian exclosure which minimizes sediment alterations. Mar. Ecol. Prog. Ser. 3: 79-81 
Blueweiss, L., Fox, H., Kudzima, V., Nakashima, D., Peters, R., Sams, D. (1978). Relationships between body size and some life history parameters. Oecologia (Berl.) 37: 257-272

Boates, J. S., Smith, P. C. (1979). Length-weight relationships, energy content and the effect of predation on Corophium voluntator (Pallas) (Crustacea: Amphipoda). Proc. N. S. Inst. Sci. 29: 489-491

Botton, M. L. (1984a). Effects of laughing gull and shorebird predation on the intertidal fauna at Cape May, New Jersey. Estuar. coast. Shelf Sci. 18: 209-220

Botton, M. L. (1984b). The importance of predation by horsesho crabs, Limulus polyphemus, to an intertidal sand flat community. J. mar. Res. 42; 139-161

Crisp, D. J. (1984), Energy flow measurements. In: Holme, N A., McIntyre, A. D. (ed.) Methods for the study of marine benthos, 2nd edn. Blackwell, Oxford, p. 284-372

De Vlas, J. (1979). Secondary production by tail regeneration in a tidal flat population of lugworms (Arenicola marina), cropped by flatfish. Neth. J. Sea Res. 13: 362-393

De Vlas, J. (1985). Secondary production by siphon regeneration in a tidal flat population of Macoma balthica. Neth. J. Sea Res. 19: 147-164

Duffy, D. C., Atkins, N., Schneider, D. C. (1981). Do shorebirds compete on their wintering grounds? Auk 98: 215-229

Edwards, D. C., Huebner, J. D. (1977). Feeding and growth rates of Polinices duplicatus preying on Mya arenaria at Barnstable Harbor, Massachusetts. Ecology 58: 1218-1236

Engelmoer, M., Piersma, T., Altenburg, W., Mes, R. (1984). The Banc d'Arguin (Mauritania). In: Evans, P.. R., GossCustard, J. D., Hale, W. G. (ed.) Coastal waders and wildfowl in winter. Cambridge Univ. Press, Cambridge, p. 293-310

Ens, B. (1982). Size selection in mussel-feeding oystercatchers. Wader Study Group Bull. 34: 16-20

Ens, B., Zwarts, L. (1980). Wulpen op het wad van Moddergat. Watervogels 5: $108-120$

Evans, P. R. (1979). Adaptations shown by foraging shorebirds to cyclical variations in the activity and availability of their intertidal invertebrate prey. In: Naylor, E., Hartnoll, R. G (ed.) Cyclic phenomena in marine plants and animals. Pergamon Press, Oxford, p. 357-366

Evans, P. R., Dugan, P. J. (1984). Coastal birds: numbers in relation to food resources. In: Evans, P. R., Goss-Custard, J. D., Hale, W. G. (ed.) Coastal waders and wildfowl in winter. Cambridge Univ. Press, Cambridge, p. 8-28

Evans, P. R., Herdson, D. M., Knights, P. J., Pienkowski, M. W. (1979). Short term effects of reclamation of part of Seal Sands, Teesmouth, on wintering waders and Shelduck. 1. Shorebirds diets, invertebrate densities, and the impact of predation on the invertebrates. Oecologia (Berl.) 41: 183-206

Federle, T W., Livingston, R. J., Meeter, D. A., White, D. C. (1983). Modifications of estuarine sedimentary microbiota by exclusion of epibenthic predators. J. exp. mar. Biol. Ecol. 73: 81-94

Furness, R. W. (1978). Energy requirements of seabird communities: a bioenergetics model. J. Anim. Ecol. 47: 39-53

Furness, R. W. (1982). Competition between fisheries and seabird communities. Adv. mar. Biol. 20: 225-307

Gee, J. M., Warwick, R. M., Davey, J. T., George, C. L. (1985). Field experiments on the role of epibenthic predators in determining prey densities in an estuarine mudflat. Estuar. coast. Shelf Sci. 21: $429-498$

Goss-Custard, J. D. (1969). The winter feeding ecology of the redshank Tringa totanus. Tbis 111: 338-356

Coss-Custard, J. D. (1977). The ecology of the Wash. III. Density-related behaviour and the possible effects of a loss of feeding grounds on wading birds (Charadrii). J. appl. Ecol. 14: 721-739

Goss-Custard, J. D. (1980). Competition for food and interference among waders. Ardea 61: 31-52

Goss-Custard, J. D. (1984). Intake rates and food supply in migrating and wintering shorebirds. In: Burger, J., Olla, B. L. (ed.) Shorebirds: migration and foraging behaviour. Plenum Press, New York, p. 233-270

Goss-Custard, J. D. (1985). Foraging behaviour of wading birds and the carrying capacity of estuaries In: Sibly, R. M., Smith, R. H. (ed.) Behavioural ecology. Blackwell, Oxford, p. 169-188

Goss-Custard, J. D., Charman, K. (1976). Predicting how many wintering waterfowl an area can support. Wildfowl 27 : $157-158$

Grant, J. (1981). A bioenergetic model of shorebird predation on infaunal amphipods. Oikos 37: 53-62

Hale, W. G. (1980). Waders. Collins, Glasgow

Hancock, D. E. Urquhart, A. (1965). The determination of natural mortality and its causes in an exploited population of cockles (Cardium edule L.). Fishery Invest. Ser. 2, Lond. 24: $1-40$.

Hockey, P. A. R., Branch, G. M. (1984). Oystercatchers and limpets: impact and implications. A preliminary assessment. Ardea 72: 199-206

Hockey, P. A. R., Siegfried, W. R., Crowe, A. A., Cooper, J. (1983). Ecological structure and energy requirements of the sandy beach avifauna of southern Africa. In: McLachlan, A., Erasmus. T. (ed.) Sandy beaches as ecosystems. Junk Publishers, Den Haag, p. 507-521

Holland, A. F., Mountford, N. K., Hiegel, M. H., Kaumeyer, D. R. Mihursky, J. A. (1980). Influence of predation on infaunal abundance in Upper Chesapeake Bay, USA. Mar. Biol. 57: 221-235

Horwood, J. W., Goss-Custard, J. D. (1977). Predation by the oystercatcher, Haematopus ostralegus (L.), in relation to the cockle, Cerastoderma edule (L.), fishery in the Burry Inlet, South Wales. J. appl. Ecol. 14: 139-158

Howard, R. K., Lowe, K. W. (1984). Predation by birds as a factor influencing the demography of an intertidal shrimp. J. exp. mar. Biol. Ecol, 74: 35-52

Hulberg, L. W., Oliver, J. S. (1980). Caging manipulations in marine softbottom communities: importances of animal interactions or sedimentary habitat modifications. Can. J. Fish. Aquat. Sci. 37: 1130-1139

Hulscher, J. B. (1975). Het wad, een overvloedig of schaars gedekte rafel voor vogels? Med. 1 Werkgroep Waddengebied, Leiden, p. 57-84

Hulscher, J. B. (1982). The oystercatcher Haematopus ostralegus as a predator of the bivalve Macoma balthica in the Dutch Wadden Sea. Ardea 70: 89-152

Kent, A. C., Day, R. W. (1983). Population dynamics of an infaunal polychaete: the effect of predators and an adultrecruit interaction. J. exp. mar Biol. Ecol. 73; 185-203

Kersten, M., Piersma, T (1987). High levels of energy expenditure in shorebirds: metabolic adaptations to an energetically expensive way of life. Ardea 75: in press

Kneib, R. T. (1982). The effects of predation by wading birds (Ardeidae) and blue crabs (Callinectes sapidus) on the population size structure of the common mummichog, Fundulus heteroclitus. Estuar. coast. Shelf Sci. 14: 159-165

Krebs, J. R., Stephens, W. D., Sutherland, W. J. (1983). Perspectives in optimal foraging. In: Clark, G. A, Brush, A. H. (ed.) Perspectives in omithology. Cambridge Univ. Press, Cambridge, p. 165-221

Mahoney, B. M. S., Livingston, R. J. (1982). Seasonal fluctua- 
tions of benthic macrofauna in the Apalachicola Estuary, Florida, USA: the role of predation. Mar Biol. 69: 207-213

Milne, H., Dunnet, G. H. (1972). Standing crop, productivity and trophic relations of the Ythan estuary. In: Barnes, R. S. K., Green, J. (ed.) The estuarine environment. Applied Science Publ., London, p. 86-106

Myers, J. P. (1984). Spacing behavior of nonbreeding shorebirds. In: Burger, J., Olla, B. L. (ed.) Shorebirds: migration and foraging behaviour Plenum Press, New York, p. 273-323

Myers, J. P., Williams، S. L., Pitelka, F. A. (1980). An experimental analysis of prey availability for sanderlings (Aves: scolopacidae) feeding on sandy beach crustaceans. Can. J. Zool. 58: 1564-1574

Nelson, W. G. (1981). Experimental studies of decapod and fish predation on seagrass macrobenthos. Mar. Ecol. Prog. Ser. 5: 141-149

Newton, L. (1980). The role of food in limiting bird numbers. Ardea 68: 11-30

O'Connor, R. J., Brown, R. A. (1977). Prey depletion and foraging strategy in the oystercatcher Haematopus ostralegus. Oecologia (Berl.) 27: 75-92

Peters, R. H. (1977). The unpredictable problems of trophodynamics. Environ. Biol. Fish. 2: 97-101

Peterson, C. H. (1979). The importance of predation and competition in organizing the intertidal epifaunal communities of Barnegat Inlet, New Jersey. Oecologia (Berl.) 39:1-24

Peterson, L. H., Quammen, M. L. (1982). Siphon napping: its importance to small fishes and its impact on the growth of the bivalve Protothaca staminea (Conrad). J. exp. mar. Biol. Ecol. 63: 249-268

Pienkowski, M. W. (1981). How foraging plovers cope with environmental effects on invertebrate behaviour and availability. In: Jones, N. V., Wolff, W. J. (ed.) Feeding and survival strategies of estuarine organisms. Plenum Press, New York, p. 179-192

Pienkowski, M.W. (1983a). Changes in the foraging pattern of plovers in relation to environmental factors. Anim. Behav. 31: $244-264$

Pienkowski, M. W. (1983b). Surface activity of some intertidal invertebrates in relation to temperature and the foraging behaviour of their shorebird predators. Mar Ecol. Prog. Ser. 11: 141-150

Pienkowski, M. W. (1983c). The effects of environmental conditions on feeding rates an prey-selection of shore plovers. Ornis Scand. 14: $227-238$

Piersma, T. (1982). Macrobenthic fauna of the intertidal flats. In: Altenburg, W., Engelmoer, M., Mes, R., Piersma, T (ed.) Wintering waders on the Banc d'Arguin, Mauritania. Stichting Veth tot steun aan Waddenonderzoek, Leiden, $\mathrm{p}$. 49-66

Piersma, T. (1986a). Foraging behaviour of Terek sandpipers Xenus cinereus feeding on sand-bubbling crabs Scopimera globosa. J. Orn. 127: 475-486

Piersma, T. (1986b). Wader foraging and benthic food production at a spring migration staging site in Morocco. Wader Study Group Bull. 47: 10

Piersma, T., Engelmoer, M. (1982). Waders and their food resources: general discussion. In: Altenburg, W., Engelmoer, M., Mes, R., Piersma, T (ed.) Wintering waders on the Banc d'Arguin, Mauritania. Stichting Veth tot steun aan Waddenonderzoek, Leiden, p. 161-164

Puttick, G. M. (1980). Energy budgets of curlew sandpipers at Langebaan Lagoon, South Africa. Estuar. coast. mar. Sci. 11: $207-215$

Quammen, M. L. (1981). Use of exclosures in studies of predation by shorebirds on intertidal mudflats. Auk 98: 812-817
Quammen, M. L. (1984). Predation by shorebirds, fish and crabs on invertebrates in intertidal mudflats: an experimental test. Ecology 65: 529-537

Reading, C. J., McGrorty, S. (1978). Seasonal variation in the burying depth of Macoma balthica (L.) and its accessibility to wading birds. Estuar. coast. mar. Sci. 6: 135-144

Reise, K. (1978). Experiments on the epibenthic predation in the Wadden Sea. Helgoländer wiss. Meeresunters. 31: 55-101

Reise, K. (1985). Tidal flat ecology. An experimental approach to species interactions. Springer-Verlag, Berlin

Robertson, A. I. (1979). The relationship between annual production: biomass ratios and lifespans for marine macrobenthos. Oecologia (Berl.) 38: 193-202

Schneider, D. C. (1981). Food supplies and the phenology of migrating shorebirds: a hypothesis. Wader Study Group Bull. 33: 43-45

Schneider, D. S. (1985a). Migratory shorebirds: resource depletion in the tropics? In: Buckley, P. A., Foster, M. S., Morton, E. S., Ridgely, R. S., Buckley, R. G. (ed.) Neotropical ornithology. Orn. Monogr. 36: 546-558

Schneider, D. S. (1985b). Predation on the urchin Echinometra lucunter (Linnaeus) by migratory shorebirds on a tropical reef flat. J. exp. mar. Biol. Ecol. 92: 19-27

Schneider, D. S., Harrington, B. A. (1981). Timing of shorebird migration in relation to prey depletion. Auk 98: 801-811

Smit, C. J. (1981). Production of biomass by invertebrates and consumption by birds in the Dutch Wadden Sea. In: Smit, C. J., Wolff, W. J. (ed.) Birds of the Wadden Sea. Balkema, Rotterdam, p. 290-301

Speakman, J. (1984). The energetics of foraging in wading birds. Ph. D. thesis, Univ. of Stirling

Summers, R. W. (1977). Distribution, abundance and energy relationships of waders (Aves: Charandrii) at Langebaan Lagoon. Trans. R. Soc. S. Afr. 42: 483-495

Summerson, H. C., Peterson, C. H. (1984). Role of predation in organizing benthic communities of temperate-zone seagrass beds. Mar. Ecol. Prog. Ser. 15: 63-77

Sutherland, W. J. (1982a). Do oystercatchers select the most profitable cockles? Anim. Behav. 30: 857-861

Sutherland, W. J. (1982b). Spatial variation in the predation on cockles by oystercatchers at Traeth Melynog, Anglesey. II. The patterns of mortality. J. Anim. Ecol. 51: 491-500

Swennen, C. (1976). Wadden Seas are rare, hospitable and productive. In: Smart, M. (ed.) Proc. Int. Conf. Cons. Wetlands and Waterfowl, Heiligenhafen, 2-6 December 1974. IRWB, Slimbridge, p. 184-198

Tinbergen, J. M. (1981). Foraging decisions in starlings (Sturnus vulgaris L.). Ardea 69: 1-67

Virnstein, R. W. (1977). The importance of predation by crabs and fishes on benthic infauna in Chesapeake Bay. Ecology 58: $1199-1217$

Virnstein, R. W. (1979). Predation on estuarine infauna: response patterns of component species. Estuaries 2: $69-86$

Waiters, J. R., Myers, J. P., Pitelka, F. A. (1981). Effects of shorebird populations on intertidal invertebrates. Wader Study Group Bull. 33: 42

Warwick, R. M., Joint, I. R., Radford, P. J. (1979). Secondary production of the benthos in an estuarine environment. In: Jefferies, R. L., Davys, A. I. (ed.) Ecological processes in coastal environments. Blackwell, Oxford, p. 429-450

Wiens, J. A., Dyer, M. I. (1977). Assessing the potential impact of granivorous birds in ecosystems. In: Pinowski, J., Kendeigh, S. C. (ed.) Granivorous birds in ecosystems. Cambridge Univ. Press, Cambridge, p. 205-266

Wolff, W. J. (1983). Benthic animals: a filter system coupling 
primary production to estuarine birds? Estuaries 6: 290-291

Wolff, W. J., van Haperen, A. M. M., Sandee, A. J. J., Baptist, H. J. M., Saeys, H. L. F. (1976). The trophic role of birds in the Grevelingen estuary, the Netherlands, as compared to their role in the saline Lake Grevelingen. In: Persoone, G., Jaspers, E. (ed.) Proc. 10th Europ. Mar. Biol. Symp., Vol. 2. Universa Press, Wetteren, p. 673-689

Young, D. K., Buzas, M. A., Young, M. W. (1976). Species densities of macrobenthos associated with seagrass: a field experimental study of predation. J. mar. Res. 34: 577-592

Zwarts, L. (1984). Het wad als vogelrijk wetland. De Levende Natuur 85: 99-103
Zwarts, L. (1986). Burying depth of the benthic bivalve Scrobicularia plana (da Costa) in relation to siphon-cropping. J. exp. mar. Biol. Ecol. 101: 25-39

Zwarts, L., Drent, R. H. (1981). Prey depletion and the regulation of predator density: oystercatchers (Haematopus ostralegus) feeding on mussels (Mytilus edulis). In: Jones, N. V., Wolff, W. J. (ed.) Feeding and survival strategies of marine organisms. Plenum Press, New York, p. 193-216

Zwarts, L., Wanink, J. (1984). How oystercatchers and curlews successively deplete clams. In: Evans, P. R., GossCustards, J. D., Hale, W. G. (ed.) Coastal waders and wildfowl in winter. Cambridge Univ. Press, Cambridge, p. 69-83

This review was submitted to the editor; it was accepted for printing on March 26, 1987 